\title{
Schooling and career aspirations of South Asian students
}

\author{
Stella Sin-tung Kwok ${ }^{{ }^{*}}$, Catherine Chiu ${ }^{2}$, Brenda Lo ${ }^{3}$, Richard $\mathrm{Wu}^{4}$ \\ From Practical Social and Industrial Research (PSIR) Symposium 2014 \\ Wanchai, Hong Kong. 5 December 2014
}

\begin{abstract}
Background
Numerous studies have been conducted in the West on the educational needs of minority students. These studies indicate that students from particular ethnic backgrounds have unsatisfactory educational experiences and various learning difficulties $[1,2]$. Although the HKSAR government, through its equal opportunity legislation, has committed itself to eliminating ethnic inequality, the South Asian minorities are confronted with various difficulties. Recent studies on the needs of these South Asian students suggest that they face various difficulties in adjusting to living in Hong Kong due to a number of interrelated factors, including insufficient Chinese language skills, lack of a tailormade Chinese curriculum for non-Chinese-speaking students, lack of knowledge about or access to available services, difficulties in finding school placements and employment opportunities, and discriminatory treatment [3]. Although many local studies have been conducted to investigate ethnic minority students' difficulties in learning Chinese [4,5], little is known about their aspirations and perceived choices in schooling, training and employment.
\end{abstract}

\section{Methods}

This paper investigates South Asian students' learning experiences and addresses issues of further studies and career preparation through understanding of their educational and vocational aspirations. Semi-structured interviews were carried out with Secondary 4 and 5 South Asian students in one designated and one nondesignated school during April and May 2013.

\section{Results}

The results reveal the diversity of needs among South Asian students during learning. The majority of the

\footnotetext{
* Correspondence: stellakwok@vtc.edu.hk

${ }^{1}$ Research Support Unit, Vocational Training Council, Hong Kong

Full list of author information is available at the end of the article
}

South Asian students interviewed aspired to 'mainstream' education and occupations, but they were acutely aware of their inability to fulfill their ambitions. Students' emphasis on making themselves work harder in the pursuit of their aspirations testifies to the entrenched ideology of competitive individualism in local society. Because a limited number of affordable educational services target South Asian students at senior secondary level in the community, this calls for increased investment of the government on after school educational services for South Asian students across all levels of schooling. However, some interviewees were not aware of other educational choices except for mainstream secondary schools and universities.

\section{Conclusions}

Educators should recognize that academic education is not the best for everyone. There are alternative education programs available for those who do not cope well in the mainstream educational path, and vocational education and training (VET) is a way to improve students' employability. Schools serving ethnic minority students are recommended to strengthen their career guidance services and make information and knowledge of VET more available to students and parents. These include technical and vocational programs targeting Secondary 3 and Secondary 6 transitions.

\footnotetext{
Authors' details

${ }^{1}$ Research Support Unit, Vocational Training Council, Hong Kong. ${ }^{2}$ Department of General Education, Technological and Higher Education Institute of Hong Kong, Hong Kong. 'Principal's Office, Youth College (Tseung Kwan O), Hong Kong. ${ }^{4}$ Department of Information \&

Communications Technology, Hong Kong Institute of Vocational Education (Tsing Yi), Hong Kong.
}

Published: 4 December 2014 


\section{References}

1. Programme for International Student Assessment:. Where immigrant students succeed: A comparative review of performance and engagement in PISA 2003 [Internet]., c-2003 [cited 2014 May 8]. Available from: http://www.oecd. org/edu/school/programmeforinternationalstudentassessmentpisa/ whereimmigrantstudentssucceed-

acomparativereviewofperformanceandengagementinpisa2003.htm\#PPP.

2. Thomson M, Crul M: The second generation in Europe and the United States: How is the transatlantic debate relevant for further research on the European second generation? J Ethn Migr Stud 2007, 33(7):1023-1041.

3. Tsung TH, Shum MSK, Ki WW: Language situation of South Asian students in Hong Kong (in Chinese). Language Situation in China: 2007 Beijing: Commercial Press; 2008.

4. Chuk J, Li DCS: Chinese literacy development: Key to ethnic minority groups' integration and social mobility in multilingual Hong Kong. Proceedings of Education, Ethnicity, and Inequality Symposium: Issues and Insights; 2013 Jul 12-13 Hong Kong: Hong Kong Baptist University; 2013.

5. Shum MSK, Zhang YH, Zhang QY, Ki WW, Ng SL: Studies of teaching Chinese as a second language to ethnic minority students in Hong Kong: Theories, challenges, and practices (in Chinese). Hong Kong: Hong Kong University Press; 2012.

doi:10.1186/2193-1801-3-S1-01

Cite this article as: Kwok et al:: Schooling and career aspirations of South Asian students. SpringerPlus 2014 3(Suppl 1):01.

\section{Submit your manuscript to a SpringerOpen ${ }^{\mathcal{O}}$ journal and benefit from:}

- Convenient online submission

- Rigorous peer review

- Immediate publication on acceptance

- Open access: articles freely available online

- High visibility within the field

- Retaining the copyright to your article

Submit your next manuscript at $\gg$ springeropen.com 